\title{
Susceptibility of Highbush Blueberry Cultivars to Phytophthora Root Rot
}

\author{
John R. Yeo \\ Department of Crop and Soil Science, 3017 ALS, Oregon State University, \\ Corvallis, OR 97331
}

Jerry E. Weiland ${ }^{2}$

U.S. Department of Agriculture, Agricultural Research Service, Horticultural Crops Research Unit, 3420 Northwest Orchard Avenue, Corvallis, OR 97330

Dan M. Sullivan
Department of Crop and Soil Science, 3017 ALS, Oregon State University,
Corvallis, OR 97331

David R. Bryla

U.S. Department of Agriculture, Agricultural Research Service, Horticultural Crops Research Unit, 3420 Northwest Orchard Avenue, Corvallis, OR 97330

Additional index words. Vaccinium corymbosum, Phytophthora cinnamomi, disease resistance, soilborne pathogen

\begin{abstract}
Phytophthora cinnamomi Rands is a ubiquitous soilborne pathogen associated with root rot in many woody perennial plant species, including highbush blueberry (Vaccinium corymbosum). To identify genotypes with resistance to the pathogen, cultivars and advanced selections of highbush blueberry were grown in a greenhouse and either inoculated or not with propagules of $P$. cinnamomi. Two experiments were conducted, including one with 10 commercially established cultivars and another with seven newly released cultivars, three commercially established cultivars, and three advanced selections of highbush blueberry. Pathogen resistance was based on the shoot and root dry biomass of the inoculated plants relative to the noninoculated plants within each genotype, as well as on the percentage of root infection among the genotypes. Resistant genotypes included four commercially established cultivars, Aurora, Legacy, Liberty, and Reka, and two new cultivars, Overtime and Clockwork. When these genotypes were inoculated, average relative shoot biomass was $\geq 60 \%$ of that of the noninoculated plants, whereas relative root biomass was $\mathbf{2 4 0} \%$. 'Star', as well as two advanced selections (an early- and a late-season type) may also have some degree of resistance, but further investigation is needed. Relative shoot biomass of the susceptible genotypes, on the other hand, ranged from $19 \%$ to $53 \%$ and relative root biomass ranged from $11 \%$ to $26 \%$. The susceptible genotypes included 'Bluetta', 'Bluecrop', 'Bluegold', 'Blue Ribbon', 'Cargo', 'Draper', 'Duke', 'Elliott', 'Last Call', 'Top Shelf', and 'Ventura'. These cultivars are not recommended at sites with conditions conducive to root rot, such as those with clay soils and/or poor drainage.
\end{abstract}

Phytophthora cinnamomi is a highly virulent root rot pathogen of highbush blueberry and is present in most growing regions

\footnotetext{
Received for publication 3 Sept. 2015. Accepted for publication 30 Nov. 2015

Financial support was provided by the Oregon Blueberry Commission, the Oregon State University Agricultural Research Foundation, and our industry contributors.

Mention of trademark, proprietary product, or vendor does not constitute a guarantee or warranty of the product by Oregon State University or the U.S. Department of Agriculture and does not imply its approval to the exclusion of other products or vendors that also may be suitable.

${ }^{1}$ Former graduate student.

${ }^{2}$ Corresponding author. E-mail: jerry.weiland@ars. usda.gov.
}

worldwide (Strik and Yarborough, 2005; Zentmyer, 1980). Symptoms of infection include poor shoot growth, root necrosis and dieback, yellowing or reddening leaves, marginal leaf necrosis, early leaf senescence, and, in the most severe cases, dead branches and canes and plant death (Caruso and Ramsdell, 1995). Root infection is more prevalent when plants are irrigated by drip than by sprinklers and occurs most commonly in heavy soils and poorly drained sites (Bryla and Linderman, 2007; de Silva et al., 1999).

Mefenoxam and phosphite (phosphonate) fungicides and certain production practices such as raised planting beds, tile drains, and proper irrigation management can help prevent phytophthora root rot (Brannen et al., 2009; Bryla and Linderman, 2007; Sterne,
1982). However, genetic resistance is currently the most effective means to control the disease (Bryla et al., 2008). The level of resistance to $P$. cinnamomi is known to vary among cultivars, but most studies have focused on rabbiteye (Vaccinium ashei Reade) or southern highbush blueberry (V. corymbosum L. interspecific hybrids) (Larach et al., 2009; Smith, 2002). Only a limited number of studies have examined differences in root rot among northern highbush cultivars $(V$. corymbosum) (Bryla et al., 2008; Erb et al., 1987). Milholland and Galletta (1967) found that northern highbush blueberry was generally more susceptible to phytophthora root rot than rabbiteye blueberry.

The objective of this study was to evaluate the response of highbush blueberry cultivars and advanced selections to $P$. cinnamomi and identify the most resistant genotypes to the pathogen. By choosing cultivars with more resistance to $P$. cinnamomi, growers may reduce economic losses related to the disease.

\section{Materials and Methods}

Evaluation of commercially established cultivars (Expt. 1). Ten cultivars grown for commercial blueberry production were evaluated for resistance to phytophthora root rot. The cultivars, in order of ripening, included Bluetta (early-season northern highbush), Duke (earlyseason northern highbush), Star (early-season southern highbush), Draper (midseason northern highbush), Bluegold (midseason northern highbush), Bluecrop (midseason northern highbush), Legacy (mid-to-late-season northern highbush), Liberty (late-season northern highbush), Elliott (very late-season northern highbush), and Aurora (very late-season northern highbush). Twelve plants of each cultivar were obtained from a nursery as 5-cm-diameter tissue culture plugs (Fall Creek Nursery, Lowell, OR), transplanted into 2.6-L containers filled with potting medium (Metro Mix 840PC; Sun Gro Horticulture, Agawam, MA), and placed on two greenhouse benches on 2 Sept. 2011. All cultivars were $\approx 1$-year old and $10-15 \mathrm{~cm}$ tall at transplanting. The greenhouse was maintained at a constant $20^{\circ} \mathrm{C}$ day/night air temperature and equipped with 1000-W high-pressure sodium lamps. The lamps were set to extend the daily photoperiod to $16 \mathrm{~h} \cdot \mathrm{d}^{-1}$.

Six plants of each cultivar were selected at random and inoculated with $P$. cinnamomi at $26 \mathrm{~d}$ after transplanting. The remaining plants served as healthy, noninoculated controls. Inoculum was prepared using a single-spore isolate of $P$. cinnamomi grown on petri dishes containing $20 \mathrm{~mL}$ of potato dextrose agar. The isolate was obtained in 2010 from a 'Draper' blueberry plant infected naturally in a field located in Corvallis, OR. The plates were fully colonized within $10 \mathrm{~d}$, after which the agar from each plate was excised and blended at $\approx 18,000 \mathrm{rpm}$ for $10 \mathrm{~s}$ with $500 \mathrm{~mL}$ of distilled water. The blended slurry was then diluted to a total volume of $6.5 \mathrm{~L}$. The mixture contained 76 colony-forming unit (cfu) per $\mathrm{mL}$ [determined by plating a $0.5 \mathrm{~mL}$ 
aliquot onto a petri dish filled with $\mathrm{P}_{10} \mathrm{ARP}$ agar, a semiselective medium for Pythiaceous species containing $10 \mathrm{ppm}$ pimaricin (SigmaAldrich, St. Louis, MO), 250 ppm ampicillin (Sigma-Aldrich), 10 ppm rifampicin (SigmaAldrich), and $100 \mathrm{ppm}$ pentachloronitrobenzene (Terrachlor, $75 \%$ a.i.; Chemtura, Middlebury, CT) (Kannwischer and Mitchell, 1978), and incubating the sample for $2 \mathrm{~d}$ at $20^{\circ} \mathrm{C}$ ]. One-hundred $\mathrm{mL}$ of the inoculum slurry was poured into each container of the inoculated treatments and washed in using a hand sprinkler. Each container from both the inoculated and the control treatments were placed in a saucer on the greenhouse benches and arranged $\approx 25 \mathrm{~cm}$ apart in a completely randomized design.

Irrigation was applied daily to each plant using an automated drip system. To encourage disease development, the plants were also hand watered, as needed, to maintain standing water in the saucers under the containers (de Silva et al., 1999). A dilute fertilizer solution (30N-10P-10K; Miracle-Gro azalea camellia rhododendron fertilizer; The Scotts Miracle-Gro Co., Marysville, $\mathrm{OH}$ ) was also applied once a week at a rate of $26 \mathrm{mg} \mathrm{N}$ per plant. The plants were harvested at 15 weeks after transplanting.

The experiment was repeated for each cultivar on 11 Apr. 2012. The only difference during the second trial was that the greenhouse was maintained at a temperature of 25 / $20{ }^{\circ} \mathrm{C}$ (day/night) with no supplemental lighting, and silver-colored, reflective shadecloth ( $60 \%$ shade reduction) was placed over the top of the greenhouse to reduce the heat load. The inoculum also contained more propagules $(122 \mathrm{cfu} / \mathrm{mL})$ and the plants were harvested at 20 weeks after transplanting.

Evaluation of new cultivars and advanced breeding selections (Expt. 2). Seven newly released cultivars and three advanced selections of highbush blueberry from Fall Creek Farm \& Nursery were also evaluated for resistance to phytophthora root rot. The cultivars included Ventura (very earlyseason southern highbush), Blue Ribbon (early-to-midseason northern highbush with $12.5 \%$ Vaccinium darrowii), Clockwork (midseason northern highbush with 25\% $\mathrm{V}$. darrowii), Top Shelf (midseason northern highbush with $5.8 \% \mathrm{~V}$. darrowii and $4.35 \%$ V. ashei), Cargo (late-season northern highbush with $5.6 \% \mathrm{~V}$. darrowii and $3.75 \%$ V. ashei), Last Call (very late-season northern highbush), and Overtime (very lateseason rabbiteye). Reka was also added to the experiment as an additional early-season northern highbush cultivar, and Draper and Legacy were included as susceptible and resistant standards, respectively. The advanced selections were designated Fall Creek (FC) selection 1 (midseason northern highbush), 2 (mid-to-late-season northern highbush with $12.5 \% \mathrm{~V}$. darrowii), and 3 (late-season northern highbush with $5.6 \% V$. darrowii and $3.75 \% \mathrm{~V}$. ashei). Twelve, 5-cm-diameter tissue culture plugs of each genotype (same size and age as in Expt. 1) were obtained from the nursery and transplanted on 16 Sept.

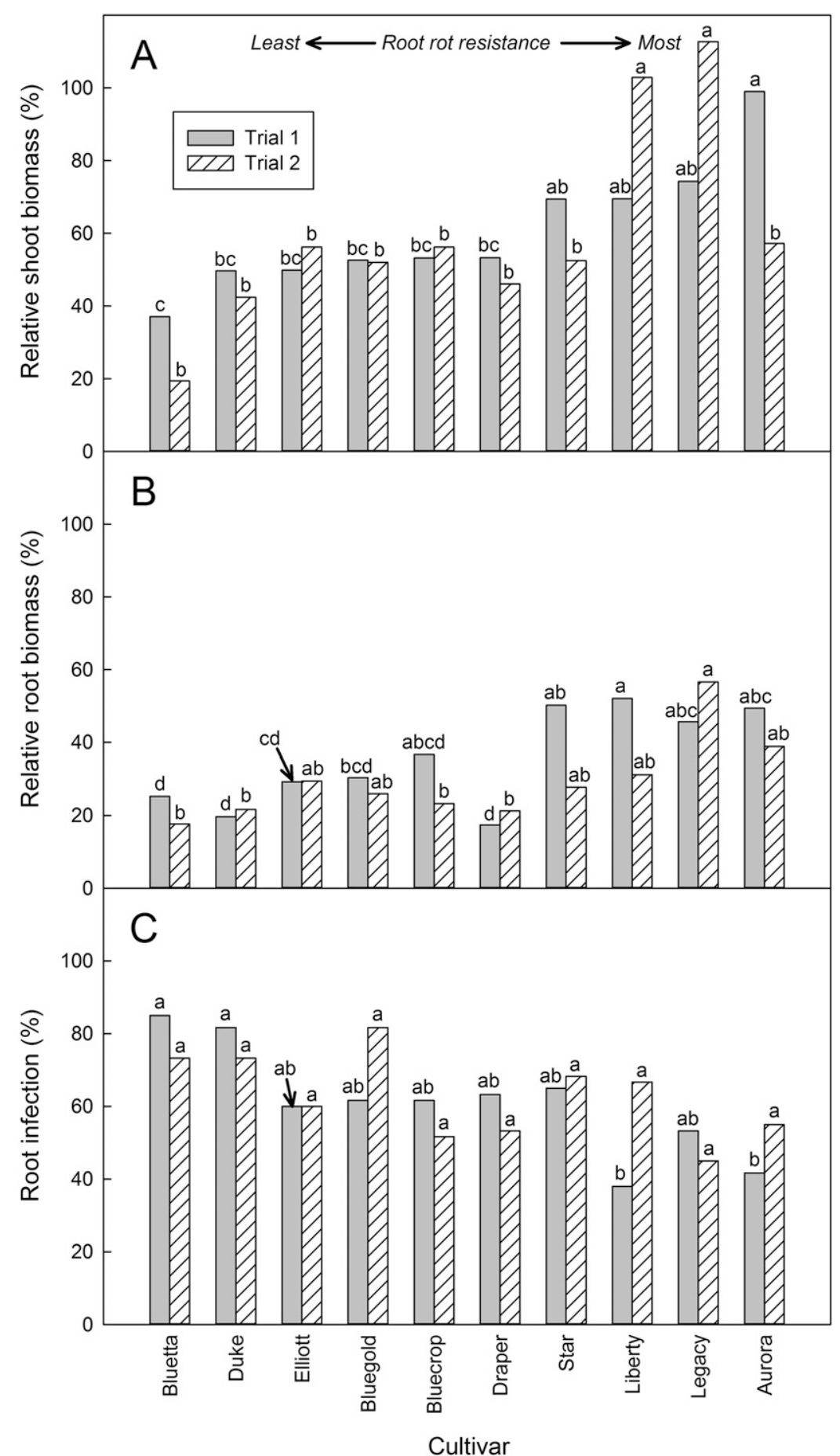

Fig. 1. (A) Relative shoot biomass, (B) relative root biomass (inoculated biomass/biomass noninoculated control), and (C) root infection by Phytophthora cinnamomi in two trials on 10 commercially established cultivars of highbush blueberry (Expt. 1). Means with the same letter within a trial are not significantly different at $P \leq 0.05$.

2013. Growth conditions and inoculation procedures were similar to those used in the first trial of Expt. 1, except that the plants were inoculated at $7 \mathrm{~d}$ after transplanting and the inoculum contained $650 \mathrm{cfu} / \mathrm{mL}$. However, this time, disease symptoms were not apparent in any of the cultivars within the first few weeks after inoculation. Communication with the nursery revealed that the plants had been treated with mefenoxam fungicide, which likely inhibited development of the disease.
Therefore, $100 \mathrm{~mL}$ of inoculum at the same concentration $(650 \mathrm{cfu} / \mathrm{mL})$ was reapplied to the inoculated treatments on 9 Nov. 2013. The plants were harvested at 16 weeks after transplanting.

Measurements. The plants from both experiments were washed and divided into shoots (stems and leaves) and roots, ovendried at $70{ }^{\circ} \mathrm{C}$, and weighed to determine the total dry biomass. Susceptibility to phytophthora root rot was expressed as the relative difference 
in dry shoot and root biomass between the inoculated and noninoculated plants within each cultivar (Allardyce et al., 2012). Relative root and shoot biomass was calculated for each inoculated plant by dividing its root and shoot biomass by the average corresponding biomass from the six noninoculated plants of the same cultivar in the same trial. Plants with an average relative shoot biomass $\geq 60 \%$ and relative root biomass $\geq 40 \%$ across both trials in Expt. 1 were considered resistant, and those with less were considered susceptible. The same criteria were also used in Expt. 2. Ten 1-cmlong root sections were also sampled from each plant before drying and plated onto petri dishes filled with $\mathrm{P}_{10} \mathrm{ARP}$ agar amended with 25 ppm hymexazol ( $\mathrm{P}_{10} \mathrm{ARPH}$; Tachigaren, $70 \%$ a.i.; Sankyo Co., Tokyo, Japan), which is selective for Phytophthora sp. (Tsao and Guy, 1977). The plates were incubated at $20^{\circ} \mathrm{C}$ and monitored periodically under a microscope $(\times 40)$ for $10 \mathrm{~d}$ to determine the percentage of the root sections infected by $P$. cinnamomi.

Statistical analysis. Data from each plant (relative root and shoot biomass and root infection incidence) were normally distributed, and therefore analyzed using the general linear model procedure in the Statgraphics Centurion XVI statistical software package (StatPoint Technologies Inc., Warrenton, VA). For Expt. 1, the model included cultivar, trial, and cultivar $\times$ trial interaction. Trial $\times$ cultivar interaction was significant for relative shoot biomass, but not relative root biomass or root infection incidence. Expt. 2 was not repeated, and the model only included cultivar. Means from each trial were separated at the 0.05 level using the Tukey's honestly significant difference test.

\section{Results and Discussion}

Evaluation of commercially established cultivars (Expt. 1). Many of the plants inoculated with $P$. cinnamomi displayed symptoms of phytophthora root rot, including leaf chlorosis, foliar reddening, and vascular discoloration and cortical rot in the roots (Caruso and Ramsdell, 1995). However, the level of response to the pathogen was variable among the cultivars. Bluetta was one of the most susceptible cultivars to root rot, producing only $37 \%$ relative shoot biomass with inoculation during the first trial and only $19 \%$ during the second trial (Fig. 1A). 'Duke' and 'Draper' were also highly susceptible to root rot and, along with 'Bluetta' and 'Bluecrop' in the second trial, produced only $25 \%$ or less relative root biomass (Fig. 1B). In many cases, inoculated plants from these four cultivars failed to produce any new roots beyond the original nursery plug. The noninoculated plants, on the other hand, showed no signs of root rot and produced numerous new roots in the potting medium. 'Elliott' and 'Bluegold' also produced on average $\leq 60 \%$ relative shoot biomass and $\leq 40 \%$ relative root biomass, and were therefore considered susceptible. Despite using only a single isolate of $P$. cinnamomi, our designation of
'Bluetta', 'Bluecrop', 'Draper', and 'Duke' as susceptible was consistent with observations from other greenhouse and field experiments. Bluetta, for example, was considered the most susceptible of six cultivars (three rabbiteye, two highbush, and one interspecific tetraploid hybrid blueberry) tested in a hydroponic system (Erb et al., 1987). 'Bluetta', 'Duke', and 'Draper' were similarly characterized as susceptible in previous research (Bryla and Linderman, 2007; Bryla et al., 2008; Larach et al., 2009; Vargas et al., 2015).

The most resistant cultivars (averaging $\geq 60 \%$ relative shoot biomass and $\geq 40 \%$ root biomass across both trials) included Aurora, Liberty, and Legacy. Aurora produced significantly more relative shoot biomass than six of the susceptible cultivars during the first trial, whereas Liberty and Legacy produced significantly more relative shoot biomass than all other cultivars during the second trial (Fig. 1A). These three cultivars generally had more relative root biomass than all of the other cultivars, although none of them generated more than $57 \%$ of the roots produced by the noninoculated plants (Fig. 1B). 'Star', which has shown intermediate to high resistance to root rot in the field (Lyrene and Sherman, 2000), was unable to be classified as resistant or susceptible in our study due to differences in response to inoculation between trials. It met our criteria for resistance in the first trial, but not in the second, resulting in an average of $61 \%$ relative shoot biomass and $39 \%$ relative root biomass across both trials. This may be an indication that there is some resistance in Star, but further evaluation of this cultivar will be necessary.

Root infection was high in the inoculated plants of each cultivar, including the three most resistant cultivars, and ranged from $38 \%$ to $85 \%$ in the first trial and $45 \%$ to $81 \%$ during the second trial (Fig. 1C). Relative shoot and root biomass of the cultivars was negatively correlated to root infection in the first trial but not in the second trial (Table 1). Root infection was likely exacerbated by ideal conditions for P. cinnamomi. The potting medium was often saturated by frequent watering and flooding in the present study, and the temperature inside the greenhouse was optimal for hyphal growth (de Silva et al., 1999; Zentmyer, 1980). High root infection in blueberry has also been attributed to limited plant host defenses against tissue colonization and to zoospore attraction to the roots (Erb et al., 1986; Milholland, 1975).

There were no symptoms of phytophthora root rot in the noninoculated plants of Expt. 1. However, growth in these plants differed among the cultivars (Table 2). On average, 'Aurora' and 'Elliott' had the lowest shoot biomass, whereas 'Bluecrop', 'Bluegold', and 'Bluetta' had the highest. There was no difference in root biomass in the first trial, but in the second trial, root biomass ranged from 3.1 to $8.2 \mathrm{~g} / \mathrm{plant}$, and root biomass was positively correlated with shoot biomass in both trials $(r=$ 0.690 and 0.771 at $P \leq 0.05$, respectively).

Despite cultivar differences in growth, the root and shoot biomass of healthy, noninoculated cultivars was not positively correlated with disease resistance indicating that the more vigorous cultivars (i.e., those with greater biomass) were not necessarily those that were more resistant to the disease. Aurora, for example, was rated as resistant, yet noninoculated control plants of this cultivar had consistently low shoot biomass. Bluetta and Bluecrop, on the other hand, were rated as susceptible, yet both had among the highest shoot biomass of all the cultivars in both trials.

Table 1. Pearson product-moment correlation coefficients $(r)$ between relative shoot and root biomass (inoculated biomass/biomass noninoculated control) and root infection by Phytophthora cinnamomi in commercially established cultivars (Expt. 1) and newly released cultivars and advanced selections (Expt. 2) of highbush blueberry. The data are from Figs. 1 and 2.

\begin{tabular}{llcr}
\hline & \multicolumn{3}{c}{ Root infection (\%) } \\
\cline { 2 - 4 } & \multicolumn{3}{c}{ Expt. 1 } \\
\cline { 2 - 4 } Dependent variable & Trial 1 & Trial 2 & Expt. 2 \\
\hline Relative shoot biomass (\%) & $-0.78^{* *}$ & $-0.47^{\mathrm{NS}}$ & $-0.74^{* *}$ \\
Relative root biomass (\%) & $-0.73^{*}$ & $-0.58^{\mathrm{Ns}}$ & $-0.86^{* * *}$ \\
\hline
\end{tabular}

Ns $, *, * *, * * *$ Nonsignificant or significant at $P \leq 0.05,0.01$, and 0.001 , respectively.

Table 2. Total dry shoot and root biomass of 10 healthy (noninoculated), commercially established cultivars of noninoculated highbush blueberry plants (Expt. 1).

\begin{tabular}{|c|c|c|c|c|}
\hline \multirow[b]{2}{*}{ Cultivar } & \multicolumn{2}{|c|}{ Shoot biomass (g/plant) } & \multicolumn{2}{|c|}{ Root biomass (g/plant) } \\
\hline & Trial 1 & Trial 2 & Trial 1 & Trial 2 \\
\hline Aurora & $8.0 \mathrm{bc}^{\mathrm{z}}$ & $10.9 \mathrm{~cd}$ & $4.7 \mathrm{a}$ & $6.9 \mathrm{ab}$ \\
\hline Bluecrop & $16.3 \mathrm{a}$ & $15.9 \mathrm{abc}$ & $5.6 \mathrm{a}$ & $6.7 \mathrm{ab}$ \\
\hline Bluegold & $14.7 \mathrm{abc}$ & $19.8 \mathrm{a}$ & $5.7 \mathrm{a}$ & $8.2 \mathrm{a}$ \\
\hline Bluetta & $15.7 \mathrm{ab}$ & $19.2 \mathrm{ab}$ & $5.5 \mathrm{a}$ & $7.7 \mathrm{ab}$ \\
\hline Draper & $7.9 \mathrm{c}$ & $13.7 \mathrm{abcd}$ & $4.5 \mathrm{a}$ & $8.1 \mathrm{a}$ \\
\hline Duke & $14.8 \mathrm{abc}$ & $12.7 \mathrm{abcd}$ & $6.4 \mathrm{a}$ & $6.2 \mathrm{abc}$ \\
\hline Elliott & $11.8 \mathrm{abc}$ & $6.9 \mathrm{~d}$ & $5.0 \mathrm{a}$ & $3.1 \mathrm{c}$ \\
\hline Legacy & $14.9 \mathrm{abc}$ & $8.9 \mathrm{~cd}$ & $4.8 \mathrm{a}$ & $4.4 \mathrm{bc}$ \\
\hline Liberty & $14.9 \mathrm{abc}$ & $8.2 \mathrm{~cd}$ & $6.0 \mathrm{a}$ & $6.0 \mathrm{abc}$ \\
\hline Star & $11.5 \mathrm{abc}$ & $11.1 \mathrm{bcd}$ & $5.5 \mathrm{a}$ & $7.2 \mathrm{ab}$ \\
\hline
\end{tabular}

${ }^{\mathrm{z}}$ Means followed by the same letter are not significantly different via Tukey's honestly significant difference test at $\alpha=0.05$. 
Evaluation of new cultivars and advanced breeding selections (Expt. 2). 'Legacy' and 'Draper' were included as resistant and susceptible standards, respectively, in Expt. 2. Although neither the relative shoot biomass nor relative root biomass were significantly different between the two cultivars in Expt. 2, the actual values were similar to those observed in both trials of Expt. 1, suggesting that these two cultivars were still useful as standards. For both experiments, 'Legacy' consistently had a relative shoot biomass $\geq 74 \%$ and relative root biomass $\geq 40 \%$, thus meeting our definition of resistance $(\geq 60 \%$ relative shoot biomass and $\geq 40 \%$ relative root biomass). In contrast, 'Draper' consistently

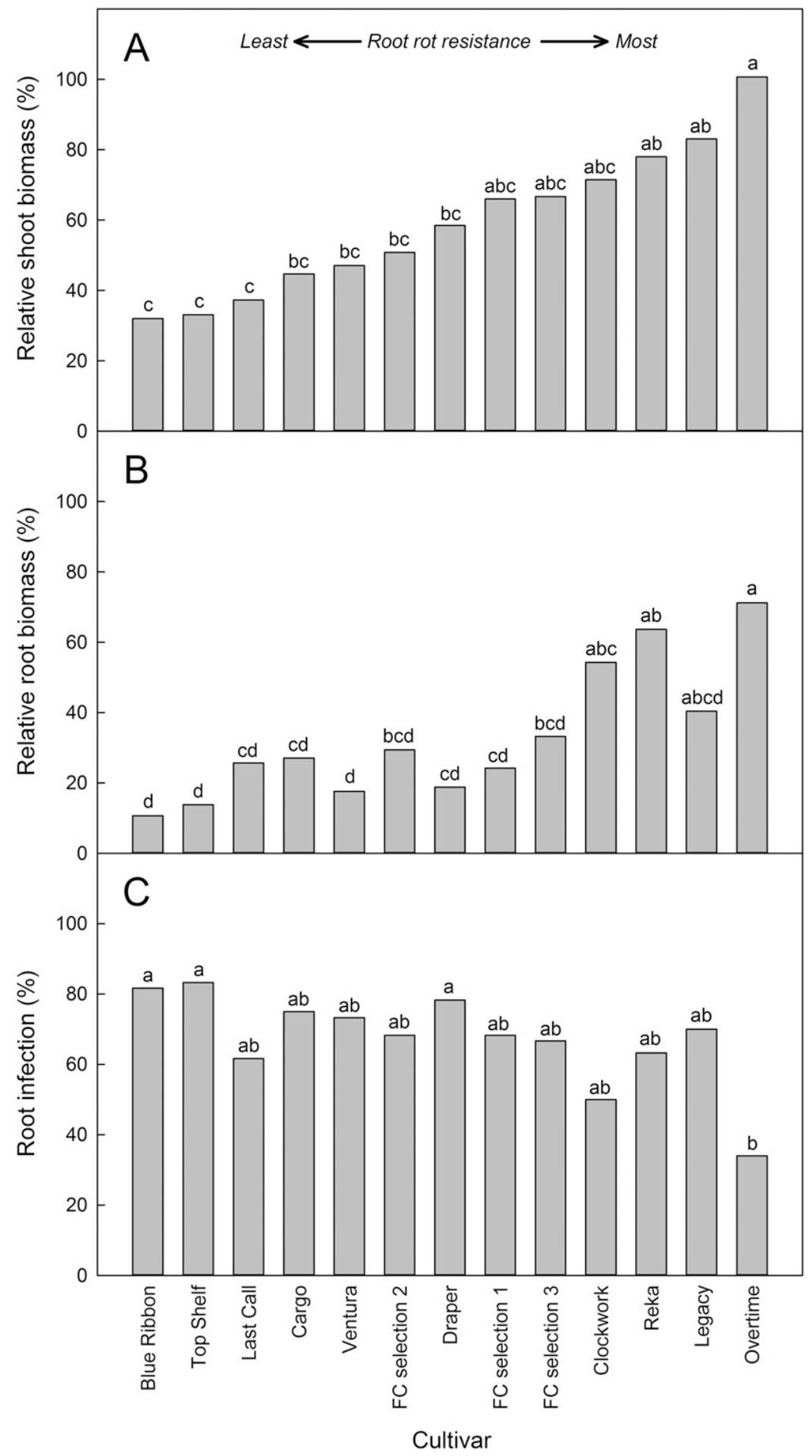

Fig. 2. (A) Relative shoot biomass, (B) relative root biomass (inoculated biomass/biomass noninoculated control), and (C) root infection by Phytophthora cinnamomi in a trial on three commercially established cultivars (Draper, Legacy, and Reka), seven newly released cultivars (Blue Ribbon, Cargo, Clock Work, Last Call, Overtime, Top Shelf, and Ventura), and three advanced selections [Fall Creek (FC) selection 1, 2, and 3] of highbush blueberry (Expt. 2). Means with the same letter are not significantly different at $P \leq 0.05$. had a relative shoot biomass $\leq 59 \%$ and relative root biomass $\leq 21 \%$, and was therefore considered susceptible. Similar to Legacy, three of the cultivars, Overtime, Reka, and Clockwork, all had $\geq 60 \%$ relative biomass and $\geq 40 \%$ relative root biomass (Fig. 2A), suggesting these cultivars are also resistant to $P$. cinnamomi and are perhaps good options for sites with a previous history of the disease. Reka has previously shown some resistance to phytophthora root rot in New Zealand (Muggleston, 1994), and Overtime is a cultivar of $V$. ashei, a blueberry species that has shown resistance to $P$. cinnamomi in previous research (Milholland and Galletta, 1967). Top Shelf, Ventura, Last Call, Cargo, Blue Ribbon, and FC selection 2, on the other hand, performed the same as or worse than Draper, suggesting these cultivars are also susceptible to root rot. Each of these latter cultivars produced $<50 \%$ relative shoot biomass (Fig. 2A) and $<30 \%$ relative root biomass of the noninfected controls (Fig. 2B). Two of the advanced highbush blueberry selections, FC selection 1 and 3, did not meet our criteria for either resistance or susceptibility. Both of these selections had $>60 \%$ relative shoot mass (resistant), but $<40 \%$ relative root mass (susceptible), which may indicate some level of intermediate resistance. Therefore, further studies to evaluate the resistance of these two selections are warranted. Relative shoot and root biomass of all of the genotypes was once again negatively correlated to root infection (Table 1). Root infection ranged from $35 \%$ to $83 \%$ and was lower in 'Overtime' than in 'Blue Ribbon', 'Top Shelf', and 'Draper' (Fig. 2C).

There were no symptoms of phytophthora root rot in the noninoculated plants in Expt. 2. Shoot biomass was relatively similar among the cultivars, ranging from 15.2 to $24.4 \mathrm{~g} /$ plant, with Blue Ribbon and Last Call having the highest shoot biomass (Table 3). Root biomass was also similar among the genotypes,

Table 3. Total dry shoot and root biomass of three healthy (noninoculated), commercially established cultivars (Draper, Legacy, and Reka), seven newly released cultivars (Blue Ribbon, Cargo, Clock Work, Last Call, Overtime, Top Shelf, and Ventura), and three advanced selections [Fall Creek (FC) selection 1,2, and 3] of noninoculated highbush blueberry plants (Expt. 2).

\begin{tabular}{lcc}
\hline Cultivar & $\begin{array}{c}\text { Shoot biomass } \\
\text { (g/plant) }\end{array}$ & $\begin{array}{c}\text { Root biomass } \\
\text { (g/plant) }\end{array}$ \\
\hline Blue Ribbon & $24.4 \mathrm{a}^{\mathrm{z}}$ & $8.3 \mathrm{ab}$ \\
Cargo & $18.0 \mathrm{ab}$ & $7.3 \mathrm{~b}$ \\
Clock Work & $23.4 \mathrm{ab}$ & $8.0 \mathrm{ab}$ \\
Draper & $18.6 \mathrm{ab}$ & $11.7 \mathrm{a}$ \\
Last Call & $24.3 \mathrm{a}$ & $7.2 \mathrm{~b}$ \\
Legacy & $16.3 \mathrm{ab}$ & $7.2 \mathrm{~b}$ \\
Overtime & $19.8 \mathrm{ab}$ & $6.2 \mathrm{~b}$ \\
Reka & $22.0 \mathrm{ab}$ & $9.6 \mathrm{ab}$ \\
FC selection 1 & $20.4 \mathrm{ab}$ & $8.3 \mathrm{ab}$ \\
FC selection 2 & $15.2 \mathrm{~b}$ & $7.1 \mathrm{~b}$ \\
FC selection 3 & $19.2 \mathrm{ab}$ & $9.1 \mathrm{ab}$ \\
Top Shelf & $20.3 \mathrm{ab}$ & $7.7 \mathrm{ab}$ \\
Ventura & $19.6 \mathrm{ab}$ & $9.8 \mathrm{ab}$ \\
\hline
\end{tabular}

${ }^{\mathrm{z}}$ Means followed by the same letter are not significantly different via Tukey's honestly significant difference test at $\alpha=0.05$. 
ranging from 6.2 to $11.7 \mathrm{~g} / \mathrm{plant}$, but was not correlated with shoot biomass. As in Expt. 1, the biomass of healthy, noninoculated cultivars was not correlated with disease resistance.

\section{Conclusion}

Genetic resistance is a promising tool for minimizing economic losses caused by phytophthora root rot. This study identified a number of blueberry cultivars with resistance to the disease, including Legacy, Liberty, Aurora, Overtime, Reka, and Clockwork. 'Star', FC selection 1, and FC selection 3 also deserve further investigation to confirm whether they have some degree of resistance. Susceptible cultivars were also identified and included Bluetta, Bluecrop, Bluegold, Blue Ribbon, Cargo, Draper, Duke, Elliott, Last Call, Top Shelf, and Ventura. Growers should avoid planting these latter cultivars on sites where the soil conditions are conducive to root rot (e.g., heavy soils and/or poor drainage).

\section{Literature Cited}

Allardyce, J.A., J.E. Rookes, and D.M. Cahill. 2012. Defining plant resistance to Phytophthora cinnamomi: A standardized approach to assessment. J. Phytopathol. 160:269-276.

Brannen, P.M., P. Harmon, and D.S. NeSmith. 2009. Utility of phosphonate fungicides for management of phytophthora root rot of blueberry. Acta Hort. 810:331-340.

Bryla, D.R. and R.G. Linderman. 2007. Implications of irrigation method and amount of water application on Phytophthora and Pythium infection and severity of root rot in highbush blueberry. HortScience 42:1463-1467.

Bryla, D.R., R.G. Linderman, and W.Q. Wang. 2008. Incidence of Phytophthora and Pythium infection and the relation to cultural conditions in commercial blueberry fields. HortScience 43:260-263.

Caruso, F.L. and D.C. Ramsdell. 1995. Compendium of blueberry and cranberry diseases. APS Press, St. Paul, MN.

de Silva, A., K. Patterson, C. Rothrock, and R. McNew. 1999. Phytophthora root rot of blueberry increases with frequency of flooding. HortScience 34:693-695.

Erb, W.A., J.N. Moore, and R.E. Sterne. 1986. Attraction of Phytophthora cinnamomi zoospores to blueberry roots. HortScience 21:1361-1363.

Erb, W.A., J.N. Moore, and R.E. Sterne. 1987. Response of blueberry cultivars to inoculation with Phytophthora cinnamomi Rands zoospores. HortScience 22:298-300.

Kannwischer, M.E. and D.J. Mitchell. 1978. The influence of a fungicide on the epidemiology of black shank of tobacco. Phytopathology 68:1760-1765.

Larach, A., X. Besoain, and E. Salgado. 2009. Crown and root rot of highbush blueberry caused by Phytophthora cinnamomi and $P$. citrophthora and cultivar susceptibility. Cienc. Investig. Agrar. 36:433-442.
Lyrene, P.M. and W.B. Sherman. 2000. 'Star' southern highbush blueberry. HortScience 35:956-957.

Milholland, R.D. 1975. Pathogenicity and histopathology of Phytophthora cinnamomi on highbush and rabbiteye blueberry. Phytopathology 65:789-793.

Milholland, R.D. and G.J. Galletta. 1967. Relative susceptibility of blueberry cultivars to Phytophthora cinnamomi. Plant Dis. Rptr. 51:999-1001.

Muggleston, S. 1994. Outstanding new blueberry cultivars developed by HortResearch. Orchardist N.Z. 67:40-42.

Smith, B.J. 2002. Susceptibility of southern highbush blueberry cultivars to phytophthora root rot. Acta Hort. 574:75-79.

Sterne, R.E. 1982. Phytophthora root rot of blueberry in Arkansas. Plant Dis. 66:604-605.

Strik, B.C. and D. Yarborough. 2005. Blueberry production trends in North America, 1992 to 2003, and predictions for growth. HortTechnology 15:391-398.

Tsao, P.H. and S.O. Guy. 1977. Inhibition of Mortierella and Pythium in a Phytophthora isolation medium containing hymexazol. Phytopathology 67:796-801.

Vargas, O.L., D.R. Bryla, J.E. Weiland, B.C. Strik, and L. Sun. 2015. Irrigation and fertigation with drip and alternative micro irrigation sprinklers in northern highbush blueberry. HortScience 50:897-903.

Zentmyer, G.A. 1980. Phytophthora cinnamomi and the diseases it causes. Monogr no. 10. APS Press, St. Paul, MN. 